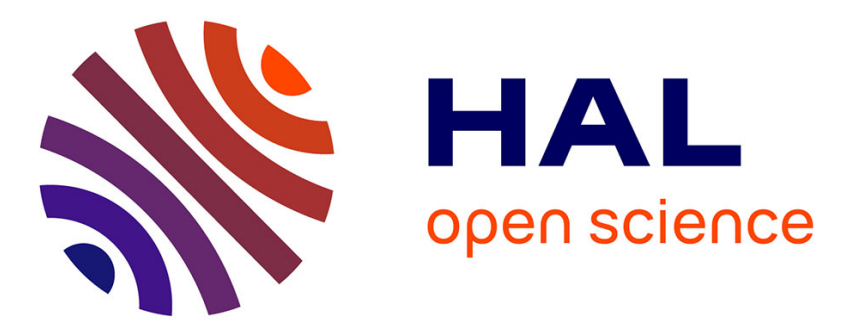

\title{
The effects of air quality on haematological and clinical parameters in children with sickle cell anaemia
}

Hrishi Mittal, Lara Roberts, Gary W. Fuller, Sandra O'Driscoll, Moira C. Dick, Sue E. Height, Swee Lay Thein, David C. Rees

\section{- To cite this version:}

Hrishi Mittal, Lara Roberts, Gary W. Fuller, Sandra O'Driscoll, Moira C. Dick, et al.. The effects of air quality on haematological and clinical parameters in children with sickle cell anaemia. Annals of Hematology, 2008, 88 (6), pp.529-533. 10.1007/s00277-008-0598-1 . hal-00477978

\section{HAL Id: hal-00477978 https://hal.science/hal-00477978}

Submitted on 30 Apr 2010

HAL is a multi-disciplinary open access archive for the deposit and dissemination of scientific research documents, whether they are published or not. The documents may come from teaching and research institutions in France or abroad, or from public or private research centers.
L'archive ouverte pluridisciplinaire HAL, est destinée au dépôt et à la diffusion de documents scientifiques de niveau recherche, publiés ou non, émanant des établissements d'enseignement et de recherche français ou étrangers, des laboratoires publics ou privés. 


\title{
The effects of air quality on haematological and clinical parameters in children with sickle cell anaemia
}

\author{
Hrishi Mittal • Lara Roberts • Gary W. Fuller • \\ Sandra O'Driscoll • Moira C. Dick • Sue E. Height • \\ Swee Lay Thein • David C. Rees
}

Received: 14 July 2008 / Accepted: 18 August 2008/Published online: 4 September 2008

(C) Springer-Verlag 2008

\begin{abstract}
Sickle cell anaemia (SCA; HbSS) is characterised by its clinical variability, which is only partly explained by known genetic factors. Environmental factors are known to contribute to acute problems but their importance in chronic complications has not been analysed. We have studied 93 children with SCA in a single institution, who underwent transcranial Doppler scanning and steady-state blood tests in 2006. These data were correlated with each individual's exposure to pollution from dust $\left(\mathrm{PM}_{10}\right)$, nitric oxide $(\mathrm{NO})$ and nitrogen dioxide $\left(\mathrm{NO}_{2}\right)$. This exposure was derived from patient postcodes and detailed street-level maps of average pollutant levels in 2006. All the pollutants correlated closely with each other. Increased exposure to pollution correlated with a significant reduction in total bilirubin levels, with a trend towards lower levels of lactate dehydrogenase and aspartate transaminase. There was
\end{abstract}

H. Mittal · G. W. Fuller

Environmental Research Group, Franklin Wilkins Building,

King's College London,

London SE1 9NH, UK

L. Roberts $\cdot$ S. O’Driscoll $\cdot$ M. C. Dick $\cdot$ S. E. Height

D. C. Rees $(\bowtie)$

Department of Paediatric Haematology,

King's College London School of Medicine,

King's College Hospital,

Denmark Hill,

London SE5 9RS, UK

e-mail: david.rees@kch.nhs.uk

S. L. Thein

Department of Haematology,

King's College London School of Medicine,

King's College Hospital,

Denmark Hill,

London SE5 9RS, UK significant correlation between extracranial internal carotid artery blood velocity and $\mathrm{PM}_{10}$ exposure. These studies suggest that chronic exposure to air pollutants could explain some variability in SCA. The lower levels of bilirubin and other markers of haemolysis with increased exposure to air pollutants could be mediated by increased exposure to NO.

Keywords Sickle cell anaemia $\cdot$ Air quality Nitric oxide . Transcranial Doppler scan · Haemolysis

\section{Introduction}

Sickle cell anaemia (SCA) is an inherited condition characterised by episodes of acute pain, acute lung problems and progressive organ damage [1]. In children, one of the main problems is the increased risk of stroke, typically associated with the narrowing of intracerebral blood vessels [2]. The clinical picture varies widely between individuals, with some children having very few problems and others being severely affected. It is not known why the disease varies so much, although genetic factors are significant and have been extensively studied [3]. Environmental factors are also likely to be important but have received little attention. We have recently started to analyse these effects on the large population of people with sickle cell disease in South London. We found that windy weather and low humidity were associated with increased hospital admissions [4]. We have also recently shown that air quality affects acute complications of sickle cell disease, with high levels of ozone $\left(\mathrm{O}_{3}\right)$ causing more episodes of acute pain. Interestingly, we also found that high levels of carbon monoxide and NO were linked to fewer hospital admissions [5]. 
Most patients with sickle cell disease in the UK and other developed countries live in urban areas with variable and often poor air quality. It seems likely that air quality has significant effects on the pathophysiology and chronic complications of SCA, as has been demonstrated for many other diseases [6]. Our previous study looked only at the effect of daily variation of air quality on admission to hospital with acute pain [5]. This study tests the hypothesis that mean annual exposure to $\mathrm{PM}_{10}, \mathrm{NO}$ and $\mathrm{NO}_{2}$ correlates with some chronic complications in children with sickle cell disease, including frequency of hospital admissions, haematological parameters and cerebrovascular disease. The study involved children less than 16 years of age for two reasons: the cerebrovascular circulation is routinely assessed using transcranial Doppler (TCD) ultrasound in this age group, and children live most of their lives close to home, allowing postcode to act as a reasonable surrogate marker of exposure to pollutants. Understanding the effects of air quality may also allow more evidence-based advice to be given on housing needs and illuminate pathological mechanisms in SCA.

\section{Patients, materials and methods}

\section{Patient population}

The study was based on children with SCA attending the Paediatric Sickle Cell Clinic at King's College Hospital who also lived in greater London. The data were anonymised prior to analysis and no extra blood samples or tests were performed. The study was discussed with the Research Ethics Committee at King's College Hospital, who decided that formal ethical approval was not necessary. Children were included in the study if they had a confirmed diagnosis of SCA (haemoglobin ( $\mathrm{Hb})$, family and DNA studies), underwent routine TCD scan and steady-state blood tests in 2006 and were documented to be living at the same address from 2005 to 2006. Patients receiving regular blood transfusions were excluded, as were those living outside London for whom air quality maps were not available. Patients are seen in clinic routinely every $3-12$ months, and steady-state blood tests are performed annually.

\section{Data collection}

Relevant data were collected from written and electronic patient records. This included assessment of haemolysis $(\mathrm{Hb}$, reticulocyte count, bilirubin, lactate dehydrogenase (LDH), aspartate transaminase (AST)), steady-state haematology ( $\mathrm{Hb}$, white cell, neutrophil and platelet counts), cerebral blood velocities from TCD scans and clinical complications (attendances at Accident and Emergency and days spent in hospital in 2006, use of hydroxyurea). The postcode was recorded routinely at each clinic attendance. The data were recorded anonymously on a secure study database.

\section{Transcranial Doppler scanning}

Intracerebral blood velocity was measured according to the protocol used in the STOP study [7] in the vascular laboratory at King's College Hospital. TCD measurements were first attempted between the ages of 2 and 4 years.

\section{Air quality mapping}

The Environmental Research Group at King's College London predicts London's air pollution using a combined modelling-measurement approach. It uses a kernel modelling technique to describe the initial dispersion of pollutants and then calculates the contribution of various sources to total air pollution concentrations by applying the model concentration field and adjusting for the source strength. A number of source types are taken into account: detailed treatment of the road network, gas combustion sources, railway sources and Heathrow airport, plus the effect of the combined road traffic emissions plus all other source types from more distant locations. The model uses hourly sequential meteorological data from the London Heathrow site. Measurements from the London Air Quality Network, which operates a series of air quality monitoring stations across London, are used to validate the model.

Local levels of $\mathrm{NO}, \mathrm{NO}_{2}$ and $\mathrm{PM}_{10}$ were mapped using the model, although equivalent maps of $\mathrm{O}_{3}$ levels were not available. These maps were used to assign a mean exposure to pollutants for 2006 to each child, based on the postcode of their home. In the UK, postcodes consist of five to eight numbers and letters, which uniquely designate a small group of houses in the same street.

\section{Analysis}

The mean annual exposure to $\mathrm{NO}, \mathrm{NO}_{2}$ and $\mathrm{PM}_{10}$ was not normally distributed and was analysed by Spearman's rank correlation $(\rho)$, using Statistical Package for Social Sciences (SPSS), version 14.0 (SPSS Inc., Chicago, IL, USA). Mean annual pollution exposure for categorical variables was analysed using the Mann-Whitney $U$ test.

\section{Results}

Patients

One hundred seven children with SCA who lived in greater London underwent TCD scanning and blood testing in 
2006 at King's College Hospital. Of these, 14 had known cerebrovascular disease and were on transfusion programmes and were not analysed further. The 93 children studied had a mean age of 8.9 years (2.5-16.4 years) and included 38 girls $(41 \%)$. Ten patients were taking hydroxyurea because of recurrent acute pain or acute chest syndrome and were included in the analyses.

\section{Air quality}

Mean annual exposure to the three pollutants analysed varied widely across the different postcodes. The mean annual exposure to pollutants was: $\mathrm{NO}_{2} 38.9 \mu \mathrm{g} / \mathrm{m}^{3}$ (median 40, range 26-51), NO $24.6 \mu \mathrm{g} / \mathrm{m}^{3}$ (median 24.5, range 8-52), $\mathrm{PM}_{10} 22.3 \mu \mathrm{g} / \mathrm{m}^{3}$ (median 22.2, range 2026). All three pollutants were very closely correlated with each other $\left(\mathrm{NO}_{2}\right.$ vs $\mathrm{NO} \rho=0.98, P<0.001 ; \mathrm{NO}_{2}$ vs $\mathrm{PM}_{10}$ $\rho=0.93, P<0.001$; NO vs $\left.\mathrm{PM}_{10} \rho=0.94, P<0.001\right)$, suggesting that they are all related to a similar aspect of air quality.

\section{Hospital attendance}

The number of days spent in hospital varied from 0 to 26 (median 0 , mean 1.96) and the number of $\mathrm{A} \& \mathrm{E}$ attendances ranged from 0 to 4 (median 0 , mean 0.37 ). There was no detectable effect of exposure to pollution for $\mathrm{NO}, \mathrm{NO}_{2}$ or $\mathrm{PM}_{10}$ on hospital use in 2006 on a number of different analyses. For example, for each pollutant, patients were divided in to two halves: those exposed to lowest levels and those exposed to highest levels. There was no difference in hospital admissions or A\&E attendance between these halves for any of the pollutants (Mann-Whitney $U$ test). Taking hydroxyurea is a marker of more severe clinical problems, and there was no difference in the mean annual exposure to pollutants in the ten children taking hydroxyurea compared to those who were not (Mann-Whitney $U$ test).

Routine laboratory measures

There was no significant correlation between exposure to $\mathrm{NO}, \mathrm{NO}_{2}$ or $\mathrm{PM}_{10}$ and haemoglobin, white cell count, platelet count, and alanine transaminase (Spearman's rank correlation; Table 1).

Measures of haemolysis

Exposure to $\mathrm{NO}, \mathrm{NO}_{2}$ and $\mathrm{PM}_{10}$ correlated negatively and significantly with total bilirubin levels (Fig. 1). There was a non-significant trend towards increasing pollution exposure being correlated with decreasing levels of LDH, AST and reticulocyte count (Table 1).

Transcranial Doppler measurements

There was significant positive correlation between exposure to all three pollutants and blood velocity in the extracranial internal carotid artery (eICA). There was a non-significant negative relationship between exposure to pollution and intracerebral blood flow in the intracranial carotid artery, middle cerebral, anterior cerebral (ACA) and posterior cerebral arteries. (Table 1).

\section{Conclusions}

This study is the first attempt to assess the effects of air quality on steady-state measurements and chronic com-

Table 1 Summary of data showing Spearman rank correlation $(r)$ and two-tailed significance $(P)$ between air pollutants, blood parameters and transcranial Doppler measurements of blood velocity

\begin{tabular}{|c|c|c|c|c|c|c|c|c|}
\hline & Number & Mean & $\mathrm{NO}_{2} \rho$ & $P$ & $\mathrm{NO} \rho$ & $P$ & $\operatorname{PM} 10 \rho$ & $P$ \\
\hline \multicolumn{9}{|l|}{ General } \\
\hline $\mathrm{Hb}(\mathrm{g} / \mathrm{dl})$ & 89 & 7.7 & 0.084 & 0.433 & 0.086 & 0.423 & 0.134 & 0.212 \\
\hline WBC $\left(\times 10^{9}\right.$ per litre $)$ & 89 & 11.7 & 0.087 & 0.418 & 0.100 & 0.353 & 0.063 & 0.558 \\
\hline Plts $\left(\times 10^{9}\right.$ per litre $)$ & 89 & 394 & -0.065 & 0.543 & -0.052 & 0.629 & -0.091 & 0.395 \\
\hline ALT (IU/l) & 84 & 23.4 & 0.169 & 0.124 & 0.159 & 0.148 & 0.166 & 0.131 \\
\hline \multicolumn{9}{|l|}{ Hemolysis } \\
\hline Bilirubin $(\mu \mathrm{M})$ & 89 & 53 & -0.210 & 0.048 & -0.223 & 0.036 & -0.257 & 0.015 \\
\hline LDH (IU/l) & 87 & 582 & -0.143 & 0.186 & -0.123 & 0.257 & -0.115 & 0.288 \\
\hline AST (IU/l) & 88 & 55 & -0.103 & 0.339 & -0.086 & 0.424 & -0.060 & 0.580 \\
\hline Retics $\left(\times 10^{9}\right.$ per litre $)$ & 89 & 301 & -0.101 & 0.346 & -0.085 & 0.430 & -0.071 & 0.508 \\
\hline \multicolumn{9}{|l|}{ TCD } \\
\hline $\operatorname{eICA}(\mathrm{cm} / \mathrm{s})$ & 93 & 151 & 0.219 & 0.035 & 0.224 & 0.031 & 0.269 & 0.009 \\
\hline TAMMV $(\mathrm{cm} / \mathrm{s})$ & 93 & 124 & -0.127 & 0.224 & -0.140 & 0.180 & -0.118 & 0.261 \\
\hline $\operatorname{ACA}(\mathrm{cm} / \mathrm{s})$ & 93 & 99 & -0.113 & 0.280 & -0.117 & 0.264 & -0.143 & 0.171 \\
\hline
\end{tabular}

Statistically significant results are shown in bold. 
a

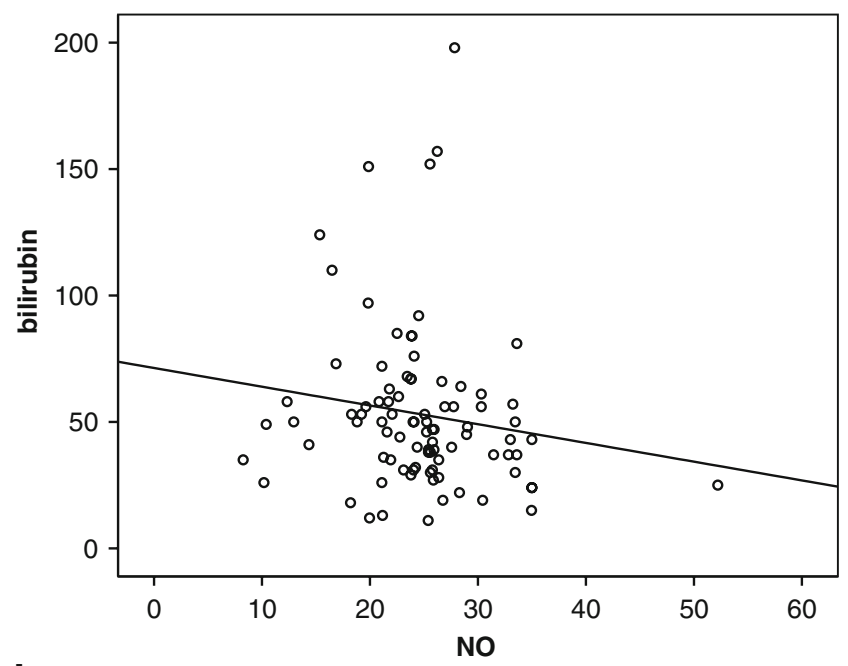

b

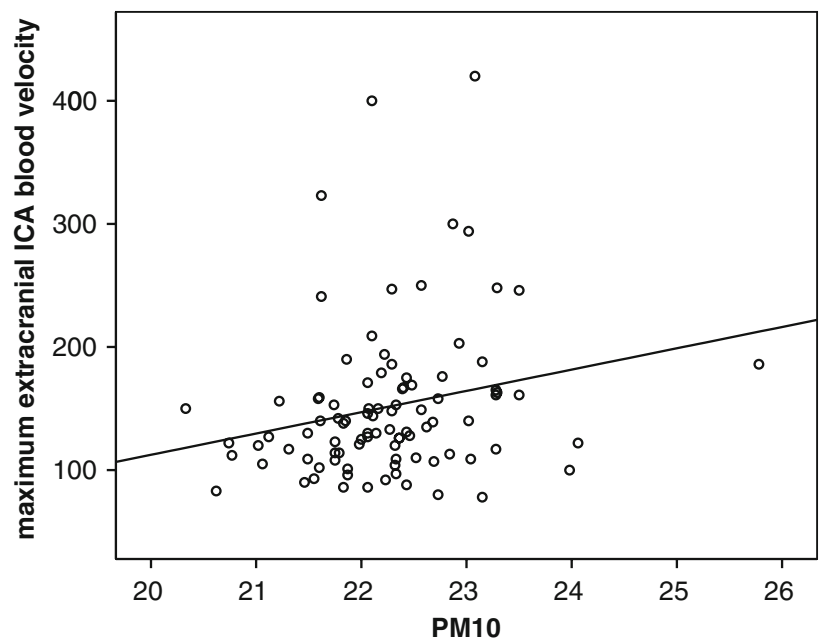

Fig. 1 a Scatter plot of exposure to nitric oxide (NO in microgramme per cubic metre) against bilirubin $(\mu \mathrm{M})$. b Scatter plot of dust exposure $\left(\mathrm{PM}_{10}\right.$ in microgramme per cubic metre) and blood velocity $(\mathrm{cm} / \mathrm{s})$ in the extracranial internal carotid artery $(\mathbf{b})$. The lines were interpolated by linear regression

plications of SCA. There are inevitably a number of limitations and confounding factors. Postcode can only act as an approximate estimate of annual exposure to pollutants, and many other factors will be important, including exposure to indoor pollutants such as tobacco smoke [8]. Equally, this study only looked at pollution exposure over a 12-month period, and some complications may occur over a longer time period and be related to environmental factors several years previously. We were also not able to analyse the effect of $\mathrm{O}_{3}$ exposure due to unavailability of maps of annual exposure at the time of the study, and we previously found this to have an important effect on increased episodes of acute pain [7]. However, despite these limitations, this study is the first to try and identify the importance of air quality on chronic complications in SCA and showed some potentially important effects.

All three pollutants showed significant negative correlation with total bilirubin. The significance of this is unclear, although a similar non-significant trend was seen for other markers of haemolysis, with $\mathrm{LDH}$, reticulocytes and AST all decreasing with increasing exposure to pollution, whilst haemoglobin shows positive correlation with NO. Haemolysis is implicated in the pathogenesis of vascular complications in SCA, with evidence that increased levels of free plasma haemoglobin cause a functional deficiency of NO [9], which contributes to a number of complications including cerebrovascular disease, priapism and leg ulcers $[10,11]$. It is interesting that increased exposure to environmental $\mathrm{NO}$ is possibly associated with decreasing haemolysis and potentially beneficial effects. This is consistent with clinical evidence of benefit from low-dose NO exposure [12] and our previous study demonstrating decreased episodes of acute pain in SCA on days with high levels of environmental NO [7].

The other significant finding in our study was a positive correlation between blood flow in the extracranial internal carotid artery and exposure to $\mathrm{NO}, \mathrm{NO}_{2}$ and $\mathrm{PM}_{10}$. This relationship was strongest between $\mathrm{PM}_{10}$ and eICA blood velocity, with a weaker effect for $\mathrm{NO}$ and $\mathrm{NO}_{2}$, consistent with the primary relationship being with $\mathrm{PM}_{10}$. The significance of increased eICA blood velocity in SCA is not established, with no evidence that it is predictive of stroke risk as has been shown for intracranial blood vessels. However, there is evidence that extracranial cerebrovascular disease is a cause of stroke in some children [13], and our study suggests that dust exposure may be contributory to this. Consistent with this, previous studies in adults without sickle cell disease have shown an association between increased exposure to $\mathrm{PM}_{10}$ and increased risk of infarctive stroke [14] and myocardial infarction [15]. It has been proposed that exposure to small particles might contribute to atherosclerotic plaque development and disruption due to demonstrable associations between $\mathrm{PM}_{10}$ levels and measures of inflammation [16], thrombosis [17] and autonomic excitation [18]. These same mechanisms might reasonably be expected to apply in children with SCA.

This study provides further evidence that air quality and environmental factors contribute to the complications of SCA. Mapping annual exposure to pollutants offers a way of analysing the effects of air quality on complications of SCA, and the findings in this study need to be confirmed in larger, prospective longitudinal studies. These effects may become more important in time due to climate change and deteriorating air quality. 


\section{References}

1. Stuart MJ, Nagel RL (2005) Sickle-cell disease. Lancet 364:13431360

2. Ohene-Frempong K, Weiner SJ, Sleeper LA, Miller ST, Embury S, Moohr JW, Wethers DL, Pegelow CH, Gill FM (1998) Cooperative study of sickle cell disease: cerebrovascular accidents in sickle cell disease: rates and risk factors. Blood 91:288-294

3. Steinberg MH (2005) Predicting clinical severity in sickle cell anaemia. Br J Hematol 129:465-481

4. Jones S, Duncan ER, Thomas N, Walters J, Dick MC, Height SE, Stephens AD, Thein SL, Rees DC (2005) Windy weather and low humidity are associated with an increased number of hospital admissions for acute pain and sickle cell disease in an urban environment with a maritime temperate climate. $\mathrm{Br} \mathrm{J}$ Hematol 131:530-533

5. Yallop D, Duncan ER, Norris E, Fuller GW, Thomas N, Walters J, Dick MC, Height SE, Thein SL, Rees DC (2007) The associations between air quality and the number of hospital admissions for acute pain and sickle-cell disease in an urban environment. Br J Hematol 136:844-848

6. Cohen AJ, Ross Anderson H, Ostro B, Pandey KD, Krzyzanowski M, Kunzli N, Gutschmidt K, Pope A, Romieu I, Samet JM, Smith K (2005) The global burden of disease due to outdoor air pollution. J Toxicol Environmental Health Part A 68:1301-1307

7. Adams RJ, McKie VC, Hsu L, Files B, Vichinsky E, Pegelow C, Abboud M, Gallagher D, Kutlar A, Nichols FT, Bonds DR, Brambilla D (1998) Prevention of a first stroke by transfusions in children with sickle cell anemia and abnormal results on transcranial Doppler ultrasonography. New England J Med 339:5-11

8. Young RC Jr, Rachal RE, Hackney RL Jr, Uy CG, Scott RB (1992) Smoking is a factor in causing acute chest syndrome in sickle cell anemia. J Nat Med Assoc 84:267-271

9. Reiter CD, Wang X, Tanus-Santos JE, Hogg N, Cannon RO 3rd, Schechter AN, Gladwin MT (2002) Cell-free hemoglobin limits nitric oxide bioavailability in sickle-cell disease. Nat Med 8:13831389

10. Kato GJ, McGowan V, Machado RF, Little JA, Taylor J, Morris CR, Nichols JS, Wang X, Poljakovic M, Morris SM, Gladwin MT (2006) Lactate dehydrogenase as a biomarker of hemolysisassociated nitric oxide resistance, priapism, leg ulceration, pulmonary hypertension, and death in patients with sickle cell disease. Blood 107:2279-2285

11. O'Driscoll S, Height SE, Dick MC, Rees DC (2008) Serum lactate dehydrogenase as a biomarker in children with sickle cell disease. Br J Hematol 140:206-209

12. Weiner DL, Hibberd PL, Betit P, Cooper AB, Botelho CA, Brugnara C (2003) Preliminary assessment of inhaled nitric oxide for acute vaso-occlusive Crisis in pediatric patients with sickle cell disease. J Am Med Assoc 289:1136-1142

13. Bhattacharya A, Newell H, Evanson J, Kirkham F, Telfer P (2007) Extracranial carotid artery occlusion in children with sickle cell disease. Br J Hematol 137(Supplement 1):73

14. Wellenius GA, Schwartz J, Mittleman MA (2005) Air pollution and hospital admissions for ischemic and hemorrhagic stroke among Medicare beneficiaries. Stroke 36:2549-2553

15. Peters A, Dockery DW, Muller JE, Mittleman MA (2001) Increased particulate air pollution and the triggering of myocardial infarction. Circulation 103:2810-2815

16. Riediker M, Cascio WE, Griggs TR, Herbst MC, Bromberg PA, Neas L, Williams RW, Devlin RB (2004) Particulate matter exposure in cars is associated with cardiovascular effects in healthy young men. Am J Respiratory Critical Care Med 169:934940

17. Nemmar A, Hoet PH, Dinsdale D, Vermylenm J, Hoylaerts MF, Nemery B (2003) Diesel exhaust particles in lung acutely enhance experimental peripheral thrombosis. Circulation 107:12021208

18. Gold DR, Litonjua A, Schwartz J, Lovett E, Larson A, Nearing B, Allen G, Verrier M, Cherry R, Verrier R (2000) Ambient pollution and heart rate variability. Circulation 101:1267-1273 